\title{
CONTROVERTION BETWEEN TEXT VERSUS CONTEXT IN INTERPRETING AL-QUR'AN
}

\author{
Muhammadong ${ }^{1}$ \\ Dedi Junaedi ${ }^{2}$ \\ Universitas Negeri Makassar $^{1}$ \\ IKIP Siliwangi Bandung ${ }^{2}$ \\ muhammadong74@yahoo.com¹, dedijunaedi585@gmail.com²
}

\begin{abstract}
The controversy referred to in this paper is not to find a clash with the qath'i texts, but to find a common perception of the two propositions so as to find the point of truth. The controversy surrounding the issue of text versus context will never be resolved because the existence and urgency of the Qur'an revealed are global in nature so that a broader interpretation is needed to give benefit to humans to be able to be applied in human muamalat problems. In understanding the propositions that are already qath'i, sometimes it is found groups who use the text approach and then use the context approach in different situations. So it is considered confusing among Muslims. Whereas the existence of the Qur'an as a revealed book is very adaptive to various problems so it must be elaborated based on the demands of the circumstances and time.
\end{abstract}

Keywords: Controversy; Text; Context; Al-Qur'an

\section{INTRODUCTION}

Al-Qur'an is a divine guidance that must be guided by humans delivered by Gabriel through his Prophet as the foundation of human life and life. Al-Qur'an is a guide for humans in social life so they do not get lost. The Qur'an was revealed to give people a sense of justice so that they could live in peace and happiness. ${ }^{1}$ The existence of the Qur'an is not a book that must be read but must be practiced so that they do not get lost. As a qath'i passage, the Qur'an certainly opens itself to reading, studying, understanding, and practicing all its messages. Human understanding is now emerging that the Qur'an must be studied in depth in order to find the truth. Because the book contains various aspects of human life as a way of live. ${ }^{2}$

Therefore, the Qur'an in various ways can solve the problems of social life because it is revealed as a way of life. So that Muslims are aware that the Qur'an can actually be a problem solving. In various studies both theoretically and practically, qath'i's propositions will not fade in one study but need to be elaborated broadly. The extent of the Qur'an is not

\footnotetext{
${ }^{1}$ Gusmian, Islah, 2015. Paradigm of Al-Qur'an Interpretation Research in Indonesia. Journal: Empiricism, Volume. 24 Number 1, January, page .3.

${ }^{2}$ Salim, Peter, 1980. The Contemporary English-Indonesian Dictionary. 7th edition. Jakarta: Modern English Press, 1996. S. Wojowasito-W. J. S. Poerwadarminta. Complete English-Indonesian Dictionary. Print. III; Bandung: Hasta.
} 


\section{Controvertion Between Text Versus Context in Interpreting Al-Qur'an}

because of the meaning contained therein but the understanding of the text and context that always opens opportunities in understanding it. ${ }^{3}$

The power of the text is supported by the presence of $i^{\prime} j \bar{a} z$ in the text itself internally and not from externally, such as the differences between the uslubes, which are different from poetry and different from prose. There are groups who try to map in Islamic discourse by interpreting the verses of the Qur'an by uprooting verses or hadith. ${ }^{4}$ Even found a group of fanatics to the text of the verse and ignore the context. The model is only one side of the content so it is easy to blame another opinion. Another group emerged with a very contrasting face, namely building Islamic discourse by making a distance with other Islamic understandings that differ from starting from human problems to problem solving. ${ }^{5}$

The issue of text versus context is not a new problem surfaced. Both the text and the context will always be an idol for adherents as long as the model can be understood. AlQur'an cannot be understood with the text alone and vice versa, but both approaches are a means of enriching the Islamic treasures. Islam does not want a system of sacralism between the two approaches, but it requires enrichment and deepening of the content so that it appears to be differentiated in interpreting the verses of the Qur'an. It's just that the commentators are sometimes initiated with two approaches, namely the interpretation of the classical model and the interpretation of the contemporary model. Both of these models are sometimes influenced by the masses of people. ${ }^{6}$

Among the deficiencies possessed by interpreters is the emergence of text fanaticism and ignoring the context and vice versa contextual fanaticism and ignoring the text so that an understanding emerges that the two are contradictory. In different situations, ideological interpretive models emerge where Interpreter ideas are very prominent in identifying problems. Al-Qur'an verses are only understood according to the ideas put forward without expressing other considerations. in its journey, both the text and the context are very possible to have a relationship in interpreting the Qur'an based on the ideas that are understood. Urgent issues that must be addressed with regard to the position of the text of the Koran in historical reality in order to treat the text so that it is relevant to reality. ${ }^{7}$

Nowadays relativism emerges which considers that the interpretation of the Qur'an is a human product so that it is possible to make mistakes in interpreting it and the meaning contained is no longer absolute. The impact arising from the understanding of relativism will give freedom to interpret without a solid foundation. To interpret the Al-Qur'an is not an easy

\footnotetext{
${ }^{3}$ Agustian Syah Nur, Advanced Indonesian-English Dictionary (Jakarta: Modern English Press 1990), page. 462 .

${ }^{4}$ Rini Fitria, 2016. Understanding Hermeneutics in Studying the Al-Qur'an Text. Alhadharah, Journal: Da'wah, Vol. 15 Number 29 pages. 82

${ }^{5}$ Masdar, F Mas'udi, 2004. "General Introduction to Islamic Paradigm and Methodology Emancipatory "in Veri Verdiansyah, Emancipatory Islam, Interpreting Religion for Practical Liberation. Jakarta: P3M.
}

${ }^{6}$ Khabibi Muhammad Lutfi, 2016. Contextualization in Nusantra Islamic Texts, IBDA, Journal: Islamic Culture. Vol 14 number 1, page. 120

${ }^{7}$ Zaprulkhan, 2017. The Qur'anic Hermeneutics Theory Fazlur Rahman. Journal: Noura, Volume. Number. 1, June, page. 35. 
task because it must be supported by the depth of knowledge related to the Qur'an such as nahwu science, neuroscience, al-balagha science, qawaaid al-tafsir and qawaaid al-hadith. These sciences are keywords that must be possessed by a Interpreter so that not wrong to interpret to find the meaning of the verse. ${ }^{8}$

The existence of the verse verse often becomes the object of debate among Muslims, not even a few are cheated with it so that often found errors in interpreting it. Yet the urgency and existence to be attained from being purified is a blessing for human life. However, in the midst of many polemic reaps, the Qur'an is able to answer the challenges faced because of its existence as a divine book. As a text, the Qur'an is always rich in knowledge because the more it is interpreted the more it will find the truth contained therein. ${ }^{9}$

Polemics that occur around the problem of the Qur'an are not in the context but in the limited text because the Qur'an is revealed not in detail so as to allow a broader context. Between the text and the context can not be separated because it is like a complementary construction of buildings. The inevitability of the meaning of the text will lead to progressive understanding because of its existence which opens a space so wide that the understanding contained therein is more dynamic. Unlike the text, the excess meaning of context is closer to the truth because of the various interpretations that are raised. The existence of texts cannot be separated from the conditions that surround them, so their level of influence is largely determined by historical factors and their subjectivity. ${ }^{10}$

Therefore, the Qur'an should be implemented based on the current context in order to find an adjustment between the text and the context. Al-Qur'an must be in the midst of society to answer all the problems it faces. However, it should not be assumed that the context that occurred during the time of the Prophet Muhammad is exactly the same as the current context because of cultural differences and conditions that occurred in the past and present. However, it must be able to see the similarities and differences to find a solution based on the printed text. $^{11}$

\section{METHOD}

There are two dimensions with different frameworks in understanding the Qur'an. First, in terms of the origin of its existence and second, in terms of material that proves to be a particular sound when it is read in the form of a series of written letters. The first uses the theological approach while the second uses the linguistic approach by adopting the culture of the community. As for this study, the authors suggest using the semantic approach as part of linguistics. The approach used by interpreting the textualization of the verse and its

\footnotetext{
${ }^{8}$ Nani Haryati. Analysis of Ibnu Asyur's Polygamy Textual Interpretation and Contextual Interpretation in the Book of Tahrir Wa Al-Tanwir. Journal: Volume 3 Number. 1, page. 87.

${ }^{9}$ Ida Yeni Rahmawati, 2016. Text Analysis and Context in the Opinion Column "Joint Training of AlKomodo 2014" Kompas. Journal: Dimensions of Education and Learning. Volume. January 5, page. 50

${ }^{10}$ Setiyanto, Danu Aries, 2019. Hoaks; Text and context in the Qur'an. Journal: Indonesian Journal of Religion and Society. Volume. 1 page. 3

${ }^{11}$ Nashr Hamid Abu Zaid,, Rethingking the Qur'an, Toward's a Humanistic Hermeneutic (Amasterdam: Humanistic Press, 2004), h. 52.
} 
contextualization in order to make it easier for someone to understand the Qur'an relating to the controversial verses that arise. Then the steps taken in carrying out the interpretation by comparing and conducting in-depth analysis of the content of the problem then drawing conclusions. $^{12}$

As a literature study, the aspect highlighted in this discussion is the controversy with the focus of the study of texts and context in interpreting the Qur'an. To find the true meaning in the locus of study, the researcher conducted an in-depth analysis of the aspects of differences in interpreting verses through textual approaches and context in understanding the Qur'an. To explain the meaning of the controversy in this study, tracing of references related to the focus of the study was carried out. Some references used include books, journals. The method used is to do interpretation and analysis related to the debate between the text versus the context so that the problem under study will focus more on the subject matter and can find answers comprehensively.

\section{III.DISCUSSION}

\section{A. Paragraph Textualization}

In English vocabulary Understanding the meaning of the text nas ${ }^{13}$ the plural form of nas is nusus meaning clear. ${ }^{14}$ But the notion of text can be stated as follows; namely: first, the Al-Qur'an Text or Hadith without seeing whether or not the intent contained therein, second, in the text Al-Qur'an and Hadith the meaning is clear. Text that means passage, text or means a copy of the Qur'an as a basis. ${ }^{15}$ Other meanings are something written for the basis of giving lessons. In the Arabic translation of the text as a text in the Qur'an and so it can be understood that the text is an explicit verse in the Qur'an or commonly called the verse qauly. ${ }^{16}$

The Shafi'i group, sees the understanding of the text as the Qur'anic text which contains a clear and definite purpose, while among the Hanafiyah groups the term nas is the meaning which is the main point of the descent of a verse. ${ }^{17}$ The notion of context also comes from English, namely context which is lexically meaningful, first; environment, around. Second; relationship of words in sentences. Context can also be interpreted as the atmosphere, circumstances or consideration of the atmosphere around the situation. Context

\footnotetext{
${ }^{12}$ Ahmad bin Faris bin Zakariya, Abil Husain, 1974. Mu’jum Maqayis al- Lughah. Juz VI. Dar al- Fikr al- Thaba,ah wa al- Nasyr wa al- Tauzi.

${ }^{13}$ John M. Echols, dan Hasan Shadly, 1995. Kamus Inggris-Indonesia. Edisi ke III. Jakarta: PT. Gramedia.

${ }^{14}$ Editorial Board of Islamic Encyclopedias, 1994. Islamic Encyclopedias. Print. III; Jakarta: PT. Endeavor.

${ }^{15}$ Asad Kalili, M.1987. Indonesian Arabic dictionary. Jakarta: Bulan Bintang.

${ }^{16}$ Yudiana, Fetria Eka, 2015. Understanding the Text and Context of the Qur'an about Business Communication. Journal: Muqtasid, Volume. 6 Number 1 June, page 6.

${ }^{17}$ Ahmad Warson Munawwir, 1984. Al-Munawwir dictionary. Yogyakarta: PP. Al-Munawwir.
} 
can also be interpreted as being in front or behind. Context can also be interpreted as included or dependent. ${ }^{18}$

In Arabic the context is interpreted as علاقة, قرينة, سياق الكلام 19 علاقة ,قرينة ,سياق الكلام i.e. direction or path of conversation, relationship to something or mean by the characteristics of something. So this context is outside the text. If the text is something explicit, then the context is something that is implied that has something to do with the text. ${ }^{20}$ Al-Qur'an is a proposition that can overcome and exceed other arguments in the course of history. It is the divine spirit of the Qur'an that makes it resistant to various criticisms and strikes. ${ }^{21}$ Al-Qur'an as a text requires Muslims to always deepen it because the Qur'an has such a broad meaning contained in it, as if the Qur'an promotes itself to be dissected so that the results achieved from the operation of the Qur'an ' the more the truth appears. The Qur'an promotes itself to be studied and the results of its study are increasingly revealed to the truth in him. ${ }^{22}$

As a central issue, the concept of the Qur'an is a reference of all existing texts even though many other texts of the Qur'an itself. ${ }^{23}$ As for the Arabic texts contained in the Qur'an, this can be interpreted by the revelation of Allah as the main reference in arguing. Muslims have a belief that the text of the Qur'an that is read today does not contradict the one stated by the Prophet because the existence of the hadith is part of the translation of the Qur'an itself so that the product produced cannot be disputed with other arguments besides the existence of Al -The Qur'an as a holy book will always be maintained its authenticity. ${ }^{24}$

As a revelation that is always maintained, it does not mean that the text does not cause multiple interpretations but the Qur'anic text will always bring up interpretations to find the truth so that it can be understood that the different interpretations are part of a blessing for humans. The Qur'anic text can be interpreted by looking at the context that occurs in society both in terms of social, cultural, and the character of that society. To interpret the verse, the technique that must be done early is to understand the text first so that it can know and believe that the Qur'an has a profound content about the knowledge contained therein so that it can provide information and ultimately become a role model for giving good to all nature.

${ }^{18}$ Reflita, 2016. Hermeneutics Controversy as Manhaj Tafsir (Considering the Use of Hermeneutics in the Interpretation of the Qur'an. Journal: Ushuluddin, Volume. 24, Number 2, July, page. 138.

${ }^{19}$ Abu Zaid,Nashr Hamid Mahfum al-nāsh, Dirāsah fi 'Ulūm al-Qur'ān, diterjemahkan LKIS dengan judul: Tekstualitas al-Qur'an, kritik terhadap Ulümul Quram (Yogyakarta: LKIS, 2002), h. 124.

${ }^{20}$ Umar Shihab, , 2005. The Contextuality of Al-Quran Thematic Study of Legal Verses in the Koran. Print. The 3rd; Jakarta: Penamadani.

21 Shabry, Muhammad Sadiq, 2011. Debate Between Text and Context. A-Fikr Journal, Vol. 15 Number 1 page. 25

22 Shihab, M. Quraish Shihab, 1997. Grounding the Koran's Function and Role of Revelation in Community LifePrint. XV; Bandung: Mizan.

${ }^{23}$ Issa Boullata, J.1996. "Modern Al-Quran Interpretation: Study of the Bintu Syati Method" in Aisyah Abdurrahman, Tafsir Bintu Syati, translated by Muzakkir Abdussalam. Bandung: Mizan.

${ }^{24}$ Achmad Khudori, 2011. Comparing Hermeneutics with Interpretation, Journal: Thaqafat, Volume. 7 Number 1 April, page 34. 
Besides being able to provide good for humans, the Qur'an also provides information to be protected from damage that can harm humans. Therefore, the linguistic aspect is crucial for the Interpreter in deciphering the meaning contained therein through his $u s l u b .^{25}$

In understanding the text, the steps that must be taken are language tools which include phonology, morphology, syntax, semantics, and those related to language issues such as language grammar. As for those related to the context of the verse that talks about social and cultural issues, it becomes a unity that can be used to uncover the meaning of the text. however, this does not mean that the tool is the only approach used in exploring the contents of the Qur'an. Even more approaches can be utilized in order to understand the textualization of the verse. As a holy book, the Qur'an is a verbal text, the naming of the text is based on the empirical fact that the Qur'an is a string of letters that form words or commonly referred to as text. Even to understand the proposition, it is found that three methods are adopted namely; text formatting, text mechanism, and text functions. ${ }^{26}$

The text formatting occupies the position of communication intraction. In this case if there is a mechanism for making the text, then the argument is not in the capacity during the lifetime of the prophet but will always experience good adaptation of culture, economy, worship through interpretation done. The Koran was revealed as a result of the communication process, so in the formation of its format many could be found, including the state of the recipient of the revelation namely the Prophet Muhammad, then the object to be addressed in that conversation was the Arab Nation as it was imposed at that time with the prevailing culture them as well as the aspects that cover them. The journey of the format of the verses of the Qur'an must be able to unite with and adapt to culture. In order to be able to change the social and cultural conditions towards the conditions of society desired by the Qur'an in accordance with the interpretation of the verses of the Qur'an ' an. It's just that the path taken through formalization has not received a response so it seems abandoned. ${ }^{27}$

In following his journey, the format of the Qur'an always follows the textualization of its verses because it is a fundamental text and has not changed. Text are able to make changes conducive so that humans can make as a guide of life and life. The advantages possessed by reason are apparently not able to compensate for the existence of the verse text format because the Qur'an can provide a shift in value without ignoring other aspects that occur in community culture. Thus, the textualization approach will give another color in interpreting the verses of the Qur'an. In the process of declining, the Qur'an was found the term ibtida' $i$ and some were found with the term sababi, namely in the first stage of the descent the Al-Qur'an still consider the situation and conditions but in the next stage the Qur'an is used to force the situation and conditions that occur. Such conditions occur because

${ }^{25}$ Muhammad Alfian, 2018. Hermeneutika Nasr Hamid Abu Zayd, Islamika, Journal: Islamic Sciences, Volume. 18 Number 1, page. 28

${ }^{26}$ Harun Nasution, 1996. Rational Islam, Ideas and Thought Prof. Dr. Harun Nasution. Bandung: Mizan.

${ }^{27}$ Abd. Rahman Dahlan, 1998. The rules of interpretation of the Koran. Print II; Bandung: Mizan 
of the sacreditation of a Interpreter so that they cannot do much when they find the text of the verse. ${ }^{28}$

Based on the rules used, that the capacity of the text must be able to give birth to various meanings. Thus, there are two reasons that can be used, namely; first, the text works through the analogy of interpreter in an intertextual way. The phenomenon of the Qur'an is seen in relation to other texts which preceded or existed when the Qur'an appeared. In Arabiyah culture, terms are found that relate to prose, parables, and poems with their respective characteristics. In relation to the texts found in this culture, the textualization of verses has two forms, similarities and differences. Through the form of equality of the phenomenon of the Qur'an understood in the perspectives of these texts, it appears in the cultural reality it has and gives its own color in the creativity of a culture that embraces it. Based on the form of difference, the Qur'an places itself as something different from these texts. It is this aspect of the abnormalities of the Qur'anic text that actually invited the attention of the Arab community at that time, so that they could not classify the text into existing texts. ${ }^{29}$

Furthermore, it can be found that it turns out that the textualization of the verse carries out its function independently with the support of the text afterwards, then the reference. In the first part if the concept of the verse in relation to the text outside, then in the second part the text works in relation to the concept of other verses that are in the main reference. In other words, the Qur'an has the role of giving explanations to other verses, because the position of the Al-Qur'an can interpret in other parts that interpret each other. The last part will discuss the problem of the meaning and function of verses, from the function of enrichment of meaning to find the point of truth into something that does not work anymore that can turn off textualization of the verse. Therefore, without understanding the text, it is certain that a commentator will get the wrong impression and understanding of the explanation of the verses of the Qur'an. ${ }^{30}$

However, along with the rapid development of knowledge of Muslims, so as to explain the verses linguistically to interpret the verses of the Qur'an while also translating and experiencing development so broadly that finding the point of truth of the Qur'an, including those who want to explore the Qur'an 'with the classical approach and contemporaryism. In the history of classical interpretations can be categorized interpretative works in the classical period with the categories of narrative interpretation, legal interpretation, rhetorical interpretation, allegorical interpretation and textual interpretation. This latter interpretation is a type of interpretation that focuses on explanations of the problem of reading the verses of the Qur'an using the lexicalism approach. ${ }^{31}$

${ }^{28}$ Ahmad Von Denffer, 1988. An Introduction to the Sciences of the Quran, translated by A. Nasir Budiman with the title: Knowledge of Al-Quran Basic Introduction. Jakarta CV. Rajawali.

${ }^{29}$ Alwi Shihab, 1997. Inclusive Islam. Print. I: Bandung: Mizan.

${ }^{30}$ Mustafa 'Azhami,. The History Of The Qur'anic Text. T.t., tp., t.th.

${ }^{31}$ Abdul Majid Asy-Syarafi ', 1998. Al-Ijtihad al-Jama'I fi al-Tasyri' al-Islami. Matter.I; Qatar: Wizarah Al-Auqaf wa Asy-Syu'un Al-Islamiyah. 
Therefore, whatever the name of the interpretation system is, it is important to present the method. When examining the method used by each reader, it will be found evident of each interpreter in his own style to find the truth produced without looking at the unilateral truth of an interpreter. Thus, the truth found in this style tends to blame others. ${ }^{32}$

\section{B. Text Controversy Versus Context}

The Qur'an has a human dimension. Therefore, its existence is always oriented to the realization of benefit for humans. It is hoped that humans can express the point of truth of the Qur'an through a text approach so that they can understand it well. The embodiment of the text cannot be ignored because the Qur'an was revealed based on the text of the verse outwardly then a new theory emerged that supported it through a context that could unite in giving an understanding of Islamic teachings. Through text messages understanding of the Qur'an is becoming clearer and easier to practice. It's just that the level of acceptance of each person's understanding becomes differentiated in understanding the meaning contained by the Qur'an. Sometimes the expressions of the meaning of the Qur'anic text are very profound and can be expressed through the symbolism of an metaphor so that the assumptions of understanding are also varied. ${ }^{33}$

The logical consequence of the difference in meaning is that the textualization of the verses of the Qur'an is also understood differently. In fact, not a few groups take positions to clarify the form of their understanding in order to gain recognition of the lags they have of the text of the verse. Because of the spectrum of understanding of Islamic teachings through deepening textualization, various styles of interpretation emerge with the method. To elaborate on the case mentioned in the Qur'an, of course one must use both an exoteric and an esoteric approach. Both models of the approach certainly have advantages and disadvantages, but the real intention to be achieved only Allah knows. ${ }^{34}$

Takwil is not a new case in understanding the Qur'an, and it is even more urgent that the commentators have in describing religious studies to form human civilization. Textualization of Al-Qur'an verses only has an important role when making takwil as a reference source. Limitations and shortcomings possessed by the commentators to be a separate solution for groups understanding takwil as a form of interpretation of the verses of the Qur'an. On this basis, there are two arguments used, first, the Regional Office as far as possible understands the role of the textualization of the verses of the Qur'an because of the specificity that is able to be understood due to the outward aspects of the verse. Secondly, the Regional Office takes a strategic role because it is supported by a variety of sources of references that others do not have because of their deeper meaning than interpretation. ${ }^{35}$

${ }^{32} \mathrm{M}$ Solahuddin, 2026. Textual and Contextual Approaches in Interpreting the Qur'an. Al-Bayan: Journal of Al-Qur'an Study and interpretation of 1.2 pages. 117.

${ }^{33}$ Abdurrahman and Adian Husaini Al-Baghdadi, 2007. Hermeneutics and interpretation of the Koran. Matter.I; Jakarta: Gema Insani.

${ }^{34}$ Ihsan Ali Fauzi,"1990. The Muslims and the Qur'anic Interpretation of the Upper Bibliographic Survey Works in Arabic ". In Ulumul Quran, Journal of Science and Culture. Number. 5. Jakarta: LSAF.

${ }^{35}$ Al-Qattan' Manna, 1993. Mabahis fi 'Ulum Al-Quran. Beirut: Mu'assasah Risalah. 
Sometimes a different perspective and the comprehension of the Qur'an makes textualization of the verse more difficult to accept. The emergence of differences in understanding the textualization of the verses of the Qur'an because it was driven from the beginning of its acceptance. How to receive verses from Allah Almighty is certainly very different from how to receive verses from Gabriel to the Messenger of Allah. So it goes on how to receive verses from the Prophet to his friends until the next period. The difference in comprehension gives a very significant difference in understanding the textualization of the verses of the Qur'an. However, this difference does not come just like that but is influenced by one's capacity and expertise. Textualization of the Qur'anic verses certainly has its own treasures that cannot be reached by humans because the secret they contain is only Allah who knows. In interpreting verses, differences also arise as a result of the influence of literature, the culture of society and the style of one's thoughts. ${ }^{36}$

When takwil becomes a model in understanding the Qur'anic verses, the nas becomes the priority scale in adapting the development of Arabic culture, because the Qur'an was revealed in its time. Takwil is the best solution to reduce textualization understandings. Because takwil offers contextualization interpretation without seeing aspects and other methods that violate it. Takwil verses of the Al-Qur'an are the basic concepts in understanding textualization because the Al-Qur'an is revealed to be very related to the implied meaning they contain. In fact, not a few of the commentators are more inclined towards takwil to find contextualization of the truth of the verse. In contrast to takwil, the method of interpretation is the idol of some commentators because it offers basic concepts besides how to understand them very simply because the level of complexity is very low because it is easily understood by all groups. This is where the striking difference between interpretation and takwil so that interpreters offer both alternatives. ${ }^{37}$

The solution to solving problems through hermeneutic interpretation is a brilliant idea in understanding the contextualization of the verse. The existence of hermeneutics is not intended to compete with other interpretive models such as interpretation and takwil but wants to provide solutions when other models are very difficult to accept because the level of understanding is very difficult. Thus, it is very necessary to bring together the hermeneutics with the Regional Office so that they can make a point of truth. In interpreting the Qur'an, a person's tendency always begins with the text of the verse to find a translation of the teachings of Islam. Departing from the text of the verse as if it makes it easier for someone to move on to the next stage because the text of the verse has its own identity that is able to classify the culture of society through a language approach. ${ }^{38}$

Hermeneutics always assumes that there are no permanent interpretations so that it gives opportunities to carry out studies. Furthermore, hermeneutics considers that the opportunity for reason is always wide open to explore casuistic issues. The hermeneutics'

${ }^{36}$ al-Zarqani, Muhammad 'Abdul al-Adzim. Mnahilul 'Irfan fi 'Ulumil Qur'an. Juz I; t.t: Darul khiyari al-Kutubi al-'Arabiyah, t.th.

${ }^{37}$ Muhammad Husain al- Dzahabi, 1976. Al-Tafsir wa al- Mufassirun. Juz I. Mesir: Dur alKutub.

${ }^{38}$ M. Dawan Raharjo Raharjo, 2005. Al-Quran Paradigm, Interpretation Methodology and Social Criticism. Print. I; Jakarta: PSAP Muhammadiyah. 
intensity will position itself as an understanding of neutralism without seeing people, groups or interests so that the limitations that are owned will always contextualize each issue. On the different side, this understanding always views human limitations as a textual group so that it considers that hermeneutics is the textualization of all problems to answer all religious issues. This understanding always assumes that the textualization of the verses of the Qur'an is an easy matter because the essence is revealed to understand outwardly without seeing other aspects arising from the contextualization of the verse because humans have supra advantages beyond their human nature. ${ }^{39}$

The position of the text that is transcendent, is not affected by the hustle and bustle of humanitarian problems. That way the text will die, because it is positioned as a monointerpretative. Because what is meant by textualization is the text of the verse itself is based on the consistency that is held in the verse is the purpose of the verse not making interpretations to find other purposes of the verse so that the Qur'an revealed both the pronunciation and its meaning will not change in the presence of paragraph contextualization. To strengthen the role of the text, the group affiliated with the textualization of the verse always takes the basis of the way the Prophet delivered to his friends about the Qur'an without interpreting. The textualization group of the verses always assumed that the Qur'an was revealed not to be understood contextually because the verses were delivered based on the text and the Prophet also said so. ${ }^{40}$

The position of the text that is transcendent, is not affected by the hustle and bustle of humanitarian problems. That way the text will die, because it is positioned as a monointerpretative. Because what is meant by textualization is the text of the verse itself is based on the consistency that is held in the verse is the purpose of the verse not making interpretations to find other purposes of the verse so that the Qur'an revealed both the pronunciation and its meaning will not change in the presence of paragraph contextualization. To strengthen the role of the text, the group affiliated with the textualization of the verse always takes the basis of the way the Prophet delivered to his friends about the Qur'an without interpreting. The textualization group of the verses always assumed that the Qur'an was revealed not to be understood contextually because the verses were delivered based on the text and the Prophet also said so. ${ }^{41}$

Basically the Qur'an is derived based on the culture that occurred at that time so that its delivery follows the conditions of its time. Al-Qur'an comes not to adapt the behavior of people but the culture must follow the will of the Qur'an so that the verses that are revealed are understood based on the text rather than based on behind the text. From the aspect of language, the Qur'an is derived based on Arabic language, but that does not mean Arabic language is exactly the language desired by Al-Qur'an. It's just that the Al-Qur'an Language can represent the conditions of the classical period with the present by looking at their

${ }^{39}$ Fakhruddin, 2005. Hermeneutics of the Koran: Controversial commercial themes. Yogyakarta: ELSAQ PRESS.

${ }^{40}$ Danu Aries Setiyanto, 2019. Hoaks; Text and context in the Qur'an. Journal: Indonesian Journal of Religion and Society. Volume. 1 page. 3.

${ }^{41}$ Abd. Muin Salim, 1999. Interpretation Methodology, An Epistemological Reconstruction, reinforces the existence of Interpretation as the Discipline of Science. Ujungpandang: IAIN Alauddin.

Jurnal Diskursus Islam 
respective conditions. Unlike the Arabic language, the language of the Qur'an sometimes offers a symbolic expression, giving rise to a deep interpretation in understanding it. Among the advantages possessed by the Qur'an because the aspects of language that are not able to compete with the Arabic language even though using the same language. But because the AlQur'an is structured based on the rules that are owned so that it can rival the Arabic language. ${ }^{42}$

The ongoing and intimate relationship between Allah and the Prophet (s) provides a fundamental paradigm regarding the unity of the Holy. It has one usual place on Muslim religious discourse on the subject to emphasize that the Prophet's person never influenced the revealed message. Even so, it never affected the revealed message. However this is not to say that God did not use this path of divine revelation at a very high personal level, or rather that the Prophet did not respond to the initiative of the Holy Essence in a very human way. This shows that the textualization of verses is authentic from the Essence of the Holy, even the Qur'an states, humans will not be able to accept all the truth at one time.

Another group emerged by building a liberal Islamic discourse. This liberal Islam always makes the idea of excisting discourses to find the difference between Islam which always annulls culture and Islam which is always loyal to the aspects of idelaism. On the other hand emerged Emancipatory Islam or called Critical Islam. The existence of this understanding starts from the humanitarian problem towards a critical reflection and theorization of change. In this understanding humans are given the freedom to express their ideals. Emancipatory understandings emerge from outside the text in the form of human problems and deconstruct and dismantle the text, and the text is used as a vehicle for liberation.

The embodiment of the text was not separated from the cultural factors that influence it. The logical consequence of the decline of the Qur'an will bear the cause that follows it so that the culture of the Arabs must follow what the Qur'an says. It is undeniable that history greatly influences the descending factor of the verse because it becomes a cause and effect and the process of its decline can certainly crystallize aspects of human life because the Qur'an is a guide to their lives. The texts delivered using the Qur'anic language certainly are not disputed by the Arabs because they can adapt to their language. So that it can be said that the textualization of the verse already existed since the beginning of the Qur'an's revelation. Contextualisas that come later are other issues that are not related to the text. There are issues of nasikh and mansukh, ${ }^{43}$ Makkiyah and Madaniyah ${ }^{44}$ Related to this, between the verses that came down in Mecca and the verses that went down in Medina there were differences in the characters in the verses caused by differences in objectives and different social settings. The

\footnotetext{
42 Anwar Harjono, 1998. Islamic law Extent and justice. Jakarta: Bulan Bintang.

${ }^{43}$ Muhammad 'Izzah Darwazah, 1962. Al-Tafsir al-Hadits. Juz XI, Mesir: Isa al- Babi alHalabi wa syurakah.

${ }^{44}$ Muhammad Andi Rosa, 2015. Basic Principles and Variety of Contextual Interpretation in the Study of the Qur'anic Text and the Hadith of the Prophet. Journal: Holistic Al-Hadith, Volume. 01, Number 02, ISSN:
} 2460-8939, page. 174. 
social and cultural setting of an area and the time when the verse descends into a context that can give meaning to the text. ${ }^{45}$

Yusuf Qardhawi as a contemporary thinker expresses the importance of the context's role in knowing the text of the verse, namely:

1. Historical factors determine the deepening of the text of the verse, especially relating to the culture of a society and all aspects of life. The Qur'an cannot be understood if it does not see the reason for the revelation of a verse. So to understand it, the historical factor has an important role in formulating the will of the Qur'an.

2. Context can act as a differentiation so that it can distinguish between formal legality with the intent and purpose of the stipulation of a verse.

3. The objective to be achieved from the revelation of the Qur'an certainly refers to the existence of the Prophet as an object. The Qur'an was revealed to naturally follow the culture of Arab society. ${ }^{46}$

The objectives to be achieved by linking the context to the history in order to be able to give lessons in interpreting the Qur'anic text, namely:

1. To be able to recognize the characteristics possessed by the Arabs in relation to the character, culture so that the Qur'an can take a role in changing their lives towards a better.

2. In order for the Muslim community to be able to recognize themselves, serious handling is needed in anticipating the problems faced.

3. Understanding of the welfare context can prevent the practice of coercive preconceptions in interpretation.

\section{Textual and Contextual Interpretation of Verses}

Al-Qur'an as a guide certainly not just read and understood the text but must be interpreted in order to find the truth. The word of God as proof of divinity certainly has a personal identity and opportunity through the text of the verse as his trademark. To melt identity and channel owned, it needs a translation of the Qur'an in depth from the philological aspects they have. The results of text analysis can treat the word of Allah swt as structured textualization of verses. Thus, the textualization of verses can be categorized as authentic texts and can even become part of religious understanding with a variety of advantages possessed.

The Qur'an as a text certainly can only be understood and interpreted transparently so that it becomes a matter of debate about its interpretation within the given period brackets. Text studies can be more interesting if there are several reviews or in understanding different contexts, so that there are several interpretations of a particular text. Since the time of the

\footnotetext{
${ }^{45}$ John Renard, 2004. Seven Doors to Islam, translated by: M. Khoirul Anam with Title: Dimensions of Islam. Print. I; Jakarta: Press Initiation.

${ }^{46}$ Yusuf Qardhawi, 1999. Kaifa Nata'malu Ma'a Al-Qur'an al-Addhim, translated by Abdul Hayyi AlKattani with the title: Interacting with the Koran. Print. I; Jakarta: Geen Insani.
} 
Companions after the death of the Prophet. until now, one source of living and dynamic interpretation is the ability of ijtihad and sharpness of Interpreter in establishing the law. ${ }^{47}$

In connection with the opportunity of ijtihad and istinbath law, it is necessary to deepen the text of the verse and take steps to anticipate those who are indoctrinated with the culture of their people without a legal basis. As a text that is not rigid, the Qur'an is always oriented forward looking at the benefits that result from human actions. Adaptation of the Qur'an to its people certainly has the ultimate goal of bringing truth into their lives so that the existence of the Qur'an is very easily accepted by humans. ${ }^{48}$

In practice, interpreting verses can be through text and context, information about time and place has an important position. It may be that one verse is better understood textually while another verse is contextual. This spirit gives someone to always analyze and can even do an early assessment before interpreting. That is how the Qur'an motivates people so that they can make concrete steps in their lives so that they do not blame each other and support one another. But the risk that must be borne if the Qur'an makes orders, then every problem must be able to be accounted for and not run from reality.

In connection with this situation, then anyone who wants to interpret the Qur'an should ideally be able to meet the criteria as an interpreter so that the resulting interpretation can be more comprehensive and not wrong so that the target to be achieved can be met properly as is the usual conditions that must be used to criterion, that is:

1. Have knowledge of Arabic so that they are able to study various fields.

2. Having knowledge of qawaid al-tafsir and the science of usul fiqhi that supports it.

3. Having knowledge of basic religious principles as the main reference.

4. Knowing the subject matter as an initial subject in the study.

To understand the interpretation of the text versus context, an example can be described as an illustration in understanding the Qur'an. For example a verse about inheritance law based on Allah's command in 4 an-nisa ' verse, namely;

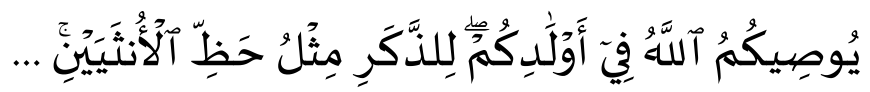

Translate:

"In the distribution of heirlooms for boys get two while girls get one, that's the rule of Allah to you"49

It is a stipulation in the distribution of inheritance that men get two while women get one from the property left by their heirs despite their position as children or siblings. It's just that there is a comparison between two and one which categorizes as an unjust act because of different circumstances and it is difficult to apply in the present situation. It's just that the

${ }^{47}$ Moh Mukri, 2017. Polygamy: Anatar Text and Social Context, Journal: Al-Sebuah, Volume: 14, Number 1, page. 205.

${ }^{48}$ Lukmanul Hakim Habibie, 2016. Hermeneutics in Islamic Studies. Journal: Fikri, Volume. 1 Number 1 , June, page. 215.

${ }^{49} \mathrm{Al}-\mathrm{Qur}$ 'an and Translation 
situation is certainly very different from comparing the present, because women's activities are now more dominant than men's activity so it takes the same treatment. ${ }^{50}$

The Qur'an was revealed not to completely eradicate Arabic culture but rather to use a persuasive approach to the Arab community in changing their doctrine. The Araa people at the time of Rasuullah peace be upon him always understood that women's activities were always passive and that their pok task was only at home to take care of the household, so it was only natural to be given one portion compared to men. The situation mentioned is no longer relevant to current conditions. Therefore, it can only be interpreted as texts, so the text of the verse explains that half of the assets owned are male. ${ }^{51}$

In addition to the distribution of inheritance, the law of cutting off hands is an object of criticism. The law of cutting off hands is considered an old-fashioned law that is not suitable to be treated in this modern age. They assume that every thief who has committed a crime must have his hands cut off. The legal provisions for cutting off hands are mentioned in 8 al-Maidah verse 8 , namely:

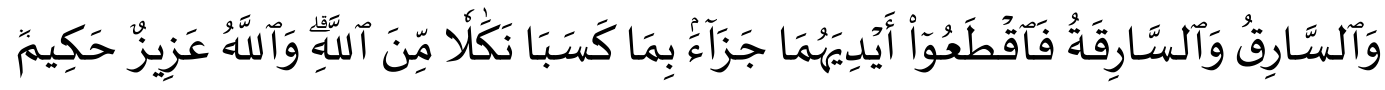

Translate :

"The legal consequences that result from committing theft are cutting off both their hands (male and female) as a reward and punishment that Allah gave to them due to their own actions and Allah is almighty and almighty. ${ }^{152}$

Textually, the meaning of the above verse is clear that the focus of attention is on punishment for the perpetrators of theft, namely cutting off hands. The pattern of interpretation that relies too much on the text and does not dare to get out of the text, so the only punishment for the crime of theft is cutting off hands. In the event that there are provisions for the stipulation of the law of cutting off hands and are free from doubt in the case of theft. ${ }^{53}$

By opening an alternative interpretation of the sentence of cutting off hands with imprisonment, because the purpose and wisdom of the sentence include "jaza'an bimakasaba nakalan minallahi" in the form of retaliation and torture in order to make lessons and make deterrent (kapok) the offender did not steal again, and certainly prevention ( preventive) for other communities. On the other hand imprisonment can also be identified with the sentence of exile from the environment of the general public, or by cutting off the ability of

${ }^{50}$ Zakiuddin Baidhawy, 2004. "Al-Ruju 'Ila Al-Qur'an': From the Fraud of Foundation Towards Hermeneutic Enlightenment ", in Pradana Boy-M. Hilmi Faiq (Ed.), Returning to the Koran Interprets the Meaning of the Age. Malang: UMM Press.

${ }^{51}$ Suyuthi Jalaluddin Abd. Al-Rahman, t.th Al-Itqan fi Ulum al-Qur'an. Juz I. Mesir: tp.,

${ }^{52} \mathrm{Al}-\mathrm{Qur}$ 'an and Translation

${ }^{53}$ Abdullah Abbas Nadwi, 1993. Learn The Language Of The Holy Qur'an, translated by the Mizan Publisher Editorial Team. Print. IV; Bandung: Mizan. 
power. ${ }^{54}$ Since the beginning of the decline of revelation until the revelation did not go down again always oriented to the benefit of the people by interacting with the cultural and social realities of the Arab people. This indicates that the Qur'an pays attention to and answers humanitarian problems, so it is very irrational when today these texts are not transformed with the increasingly complex reality of life.

Therefore, thoughts as alternative interpretations with methods or approaches from tracking texts to revealing contextual nature so as to find answers and alleviation of humanitarian problems and interpret the times. Through comprehensive interpretation problem solving will be found as a way out of the problems of today's society. In connection with the debate between the text and the context, it is necessary to give an appreciation of the results of research and opinions of previous Ulama while holding the principles that are always developed by the Organization of ahdhatul Ulama, namely: maintaining an old culture but always oriented to the benefit and consistent with new cases that can give better benefit.

\section{IV.CONCLUSION}

As a holy book in the form of the text of the Qur'an, its authenticity has been maintained from the first revealed to the end of time and is not easily replaced by khurafat. As a holy book, the texts of the Qur'an can give rise to various responses from various groups. Among them; the fundamentalist group of libarism which says that the Qur'an is a text which has a monointeritive interpretation style and is only explicitly written. The argument used as a guide because with the text can understand the meaning of the content of the Qur'an and does not require any other interpretation. In different groups, they try to approach contextually and try to get out of fanaticism in the text of the verse. They argued that the textual approach was a product of the culture of the Arabs so that the interpretation method carried out departed from humanitarian problems not based on the text of the verse.

The controversy of the text versus context will never stop with the existence of the descent of the Qur'an as rahmatan lilaalamin so that it requires a broader interpretation. The controversy is not to find a clash between the two approaches mentioned but to find the point of truth of the Qur'an through the arguments used. As a holy book, the Qur'an is very adaptive to various humanitarian problems that demand solutions to various problems that occur so that it is not considered rigid in interpreting verses in order to develop and deepen the Qur'an. The text and context approach aims to give birth to a comprehensive understanding in order to be able to answer the challenges and technological advances because the essence is purified by the Qur'an so that it can be adjusted along with the passage of time and place.

${ }^{54}$ Sheikh Ahmad Ali al-Jurjani, 1992. Hikmat al-Tasyri wa Falsafatuh, translated by Hadi Mulyo, Philosophy and Wisdom of Islamic Law. Semarang: CV. Ash-Syifa. 


\section{REFERENCES}

Al-Qur'an and Translation

Abbas Nadwi, Abdullah, 1993. Learn The Language Of The Holy Qur'an, translated by the Mizan Publisher Editorial Team. Print. IV; Bandung: Mizan.

Abu Zayd, Nashr Hamid, 2004. Rethinking the Quran, Towards a Humanistic Hermeneutic Amsterdam: Humanistic Press.

Abd. Al-Rahman, Suyuthi Jalaluddin. Al-Itqan fi Ulum al-Qur'an. Juz I. Mesir: tp., t.th.

Ali Fauzi, Ihsan. "1990. The Muslims and the Qur'anic Interpretation of the Upper Bibliographic Survey Works in Arabic ". In Ulumul Quran, Journal of Science and Culture. Number. 5. Jakarta: LSAF.

Alfian, Muhammad, 2018. Hermeneutika Nasr Hamid Abu Zayd, Islamika, Journal: Islamic Sciences, Volume. 18 Number 1, page. 28

Ali al-Jurjani, Sheikh Ahmad, 1992. Hikmat al-Tasyri wa Falsafatuh, translated by Hadi Mulyo, Philosophy and Wisdom of Islamic Law. Semarang: CV. Ash-Syifa.

Ahmad bin Faris bin Zakariya, Abil Husain, 1974. Mu'jum Maqayis al-Lughah. Juz VI. T.t: Dar al- Fikr al- Thaba,ah wa al- Nasyr wa al- Tauzi.

Al-Baghdadi, Abdurrahman and Adian Husaini, 2007. Hermeneutics and interpretation of the Koran. Matter.I; Jakarta: Gema Insani.

'Azhami, Mustafa. The History Of The Qur'anic Text. T.t., tp., t.th.

Baidhawy, Zakiuddin, 2004. "Al-Ruju 'Ila Al-Qur'an': From the Fraud of Foundation Towards Hermeneutic Enlightenment ", in Pradana Boy-M. Hilmi Faiq (Ed.), Returning to the Koran Interprets the Meaning of the Age. Malang: UMM Press.

Boullata, J. Issa, 1996. "Modern Al-Quran Interpretation: Study of the Bintu Syati Method" in Aisyah Abdurrahman, Tafsir Bintu Syati, translated by Muzakkir Abdussalam. Bandung: Mizan.

Dahlan, Abd. Rahman, 1998. The rules of interpretation of the Koran. Print II; Bandung: Mizan

Darwazah, Muhammad 'Izzah, 1962. Al-Tafsir al-Hadits. Juz XI, Mesir: Isa al- Babi alHalabi wa syurakah.

Echols, M. John dan Hasan Shadly, 1995. Kamus Inggris-Indonesia. Edisi ke III. Jakarta: PT. Gramedia.

Editorial Board of Islamic Encyclopedias, 1994. Islamic Encyclopedias. Print. III; Jakarta: PT. Endeavor.

Fakhruddin, 2005. Hermeneutics of the Koran: Controversial commercial themes. Yogyakarta: ELSAQ PRESS. 
Fitria, Rini, 2016. Understanding Hermeneutics in Studying the Al-Qur'an Text. Alhadharah, Journal: Da'wah, Vol. 15 Number 29 pages. 82

Gusmian, Islah, 2015. Paradigm of Al-Qur'an Interpretation Research in Indonesia. Journal: Empiricism, Volume. 24 Number 1, January, page .3.

Habibie, Lukmanul Hakim M, 2016. Hermeneutics in Islamic Studies. Journal: Fikri, Volume. 1 Number 1, June, page. 215.

Harjono, Anwar , 1998. Islamic law Extent and justice. Jakarta: Bulan Bintang.

Haryati, Nani, 2017. Analysis of Ibnu Asyur's Polygamy Textual Interpretation and Contextual Interpretation in the Book of Tahrir Wa Al-Tanwir. Journal: Volume 3 Number. 1, page. 87.

Husain al- Dzahabi, Muhammad, 1976. Al-Tafsir wa al- Mufassirun. Juz I. Mesir: Dur alKutub.

Kalili, M. Asad, 1987. Indonesian Arabic dictionary. Jakarta: Bulan Bintang.

Khudori, Achmad Khudori, 2011. Comparing Hermeneutics with Interpretation, Journal: Thaqafat, Volume. 7 Number 1 April, page 34.

Lutfi, Khabibi Muhammad, 2016. Contextualization in Nusantra Islamic Texts, IBDA, Journal: Islamic Culture. Vol 14 number 1, page. 120

Masudi, F. Masdar, 2004. "General Introduction to Islamic Paradigm and Methodology Emancipatory "in Veri Verdiansyah, Emancipatory Islam, Interpreting Religion for Practical Liberation. Jakarta: P3M.

Munawwir, Ahmad Warson, 1984. Al-Munawwir dictionary. Yogyakarta: PP. AlMunawwir.

Mukri, Moh., 2017. Polygamy: Anatar Text and Social Context, Journal: Al-Sebuah, Volume: 14, Number 1, page. 205.

Nasution, Harun, 1996. Rational Islam, Ideas and Thought Prof. Dr. Harun Nasution. Bandung: Mizan.

Nur, Agustian Syah Nur, Advanced Indonesian-English Dictionary (Jakarta: Modern English Press 1990), page. 462.

Qardhawi, Yusuf, 1999. Kaifa Nata'malu Ma'a Al-Qur'an al-Addhim, translated by Abdul Hayyi Al-Kattani with the title: Interacting with the Koran. Print. I; Jakarta: Geen Insani.

Al-Qattan' Manna, 1993. Mabahis fi 'Ulum Al-Quran. Beirut: Mu'assasah Risalah.

Raharjo, M. Dawan Raharjo, 2005. Al-Quran Paradigm, Interpretation Methodology and Social Criticism. Print. I; Jakarta: PSAP Muhammadiyah.

Rahmawati, Ida Yeni, 2016. Text Analysis and Context in the Opinion Column "Joint Training of Al-Komodo 2014" Kompas. Journal: Dimensions of Education and Learning. Volume. January 5, page. 50 
Reflita, 2016. Hermeneutics Controversy as Manhaj Tafsir (Considering the Use of Hermeneutics in the Interpretation of the Qur'an. Journal: Ushuluddin, Volume. 24, Number 2, July, page. 138.

Renard, John, 2004. Seven Doors to Islam, translated by: M. Khoirul Anam with Title: Dimensions of Islam. Print. I; Jakarta: Press Initiation.

Rosa, Muhammad Andi, 2015. Basic Principles and Variety of Contextual Interpretation in the Study of the Qur'anic Text and the Hadith of the Prophet. Journal: Holistic AlHadith, Volume. 01, Number 02, ISSN: 2460-8939, page. 174.

Salim, Peter, 1980. The Contemporary English-Indonesian Dictionary. 7th edition. Jakarta: Modern English Press, 1996. S. Wojowasito-W. J. S. Poerwadarminta. Complete English-Indonesian Dictionary. Print. III; Bandung: Hasta.

Salim, Abd. Muin, 1999. Interpretation Methodology, An Epistemological Reconstruction, reinforces the existence of Interpretation as the Discipline of Science. Ujungpandang: IAIN Alauddin.

Setiyanto, Danu Aries, 2019. Hoaks; Text and context in the Qur'an. Journal: Indonesian Journal of Religion and Society. Volume. 1 page. 3

Shihab, M. Quraish Shihab, 1997. Grounding the Koran's Function and Role of Revelation in Community Life. Print. XV; Bandung: Mizan.

Shihab, Umar, 2005. The Contextuality of Al-Quran Thematic Study of Legal Verses in the Koran. Print. The 3rd; Jakarta: Penamadani.

Shihab, Alwi, 1997. Inclusive Islam. Print. I: Bandung: Mizan.

Shabry, Muhammad Sadiq, 2011. Debate Between Text and Context. A-Fikr Journal, Vol. 15 Number 1 page. 25

Solahuddin, M, 2026. Textual and Contextual Approaches in Interpreting the Qur'an. AlBayan: Journal of Al-Qur'an Study and interpretation of 1.2 pages. 117.

Asy-Syarafi ', Abdul Majid, 1998. Al-Ijtihad al-Jama'I fi al-Tasyri' al-Islami. Matter.I; Qatar: Wizarah Al-Auqaf wa Asy-Syu'un Al-Islamiyah.

Von Denffer, Ahmad, 1988. An Introduction to the Sciences of the Quran, translated by A. Nasir Budiman with the title: Knowledge of Al-Quran Basic Introduction. Jakarta CV. Rajawali.

Yudiana, Fetria Eka, 2015. Understanding the Text and Context of the Qur'an about Business Communication. Journal: Muqtasid, Volume. 6 Number 1 June, page 6.

al-Zarqani, Muhammad 'Abdul al-Adzim. Mnahilul 'Irfan fi 'Ulumil Qur'an. Juz I; t.t: Darul khiyari al-Kutubi al-'Arabiyah, t.th.

Zaprulkhan, 2017. The Qur'anic Hermeneutics Theory Fazlur Rahman. Journal: Noura, Volume. Number. 1, June, page. 35. 
Zaid, Nashr Hamid Abu, Mahfum al-nāsh, Dirāsah fi 'Ulūm al-Qur'ān, diterjemahkan LKIS dengan judul: Tekstualitas al-Qur'an, kritik terhadap Ulümul Quram (Yogyakarta: LKIS, 2002), h. 124.

, Rethingking the Qur'an, Toward's a Humanistic Hermeneutic (Amasterdam: Humanistic Press, 2004), h. 52

354 Jurnal Diskursus Islam

Volume 9 Nomor 2, August 2021 